๑RDINES MILITARES COLLOQUIA TORUNENSIA HISTORICA Yearbook for the Study of the Military Orders

\section{Givlia Rossi Vairo}

Centro de Investigação e Estudos em Belas Artes, Faculdade de Belas Artes,

Universidade de Lisboa

Largo da Academia Nacional de Belas Artes, P-1249-058 Lisboa

Portugal
Instituto de Estudos Medievais, Faculdade de Ciências Sociais e Humanas, Universidade Nova de Lisboa

Av. de Berna 26 C

P-1069-061 Lisboa

Portugal

grossivairo@fcsh.unl.pt

\title{
THE DISSOLUTION OF THE ORDER OF THE TEMPLE AND THE CREATION OF THE ORDER OF CHRIST IN PORTUGAL*
}

\author{
KEYWORDS \\ King Dinis of Portugal; Papacy; Infant Afonso; Order of Christ; Order of the Temple \\ i. The foundation of the Order of Christ, Seen from Avignon and \\ FROM LISBON
}

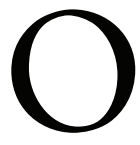

n March I4, I 3 19, with the bull Ad ea ex quibus, Pope John XXII, at the request of King Dinis of Portugal, represented by his envoys - the knight João Lourenço de Monsaraz and the canon of the Cathedral of Coimbra, Pedro Peres (or Pires) - officially established the Ordo Militie Jesu Christi, the Order of Christ. This was the de facto heir of the material and spiritual heritage of the Order of the Temple in the kingdom. ${ }^{1}$

* This paper has been revised with the support of FCT - Foundation for Science and Technology (Fundação para a Ciência e a Tecnologia) under the strategic project UID/HIS/00749/2013. The following abreviations will be used: ANTT, Gav. = Lisbon, Arquivo Nacional da Torre do Tombo, Gavetas; ANTT, LN-LM = Lisbon, Arquivo Nacional da Torre do Tombo, Leitura Nova, Livro de Mestrados; ANTT, OCCT = Lisbon, Arquivo Nacional da Torre do Tombo, Ordem de Cristo-Convento de Tomar.

1 Monumenta Henricina, vol. 1, Coimbra 1960, doc. 61, pp. 97-110.

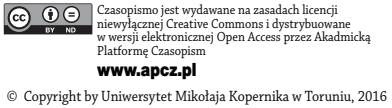


At the beginning of the document, the pontiff declared that, after listening to the ambassadors of the Portuguese sovereign, he had decided to institute a new militia, defined as pugillum Christi, "the fist of Christ", or "handful of Christ". During several preliminary meetings, these agents had, in fact, reported the innumera damna et multiplicia et enormia mala perpetrated in the past, but continuing in the present, by perfidi Sarraceni, enemies of the faith, to the detriment of the population in the south of the country. In an attempt to resolve this, the emissaries had suggested the creation of a new military order. Its mission was not only to resist the attempted attacks, reject aggressions, and defend the territory of the kingdom; it was also to fight for the reacquisition of lands, unjustly occupied by "infidels".

Welcoming the proposal of the Portuguese envoys, the pope fixed the headquarters of the new order in Castro Marim, located in the diocese of Silves, in the kingdom of Algarve. The king had promised to give the fortress in perpetuity to the newly-found order. This location had been chosen because of its strategic position, which allowed for excellent control over the land border with Castile and over a part of the Algarve coast (in the south of Portugal), and because of its position atop a hill which made the stronghold impregnable. At the same time, Pope John XXII granted to the order the nearby parish church of St Mary, which was to become its main religious centre. He also required the knights to profess the Rule of the Order of Calatrava, enjoying the same privileges. He appointed Gil Martins, a former master of the Order of Avis and professor of the Order of Calatrava, as the first master of the Order of Christ, praising him as an upright man and zealous in faith.

The new militia received all the properties, movable and immovable, both ecclesiastical and secular, which had once belonged to the Templars. The most important of these - Castelo Branco, Longroiva, Tomar and Almourol - were listed by name, along with further castles, fortifications, assets, as well as churches, chapels and oratories.

The abbot of St Mary of Alcobaça, the mother house of the Cistercians in the Portuguese kingdom, located in the diocese of Lisbon, was appointed by the pope to take responsibility for the officium correctionis of the order and entrusted to carry out visitations to its convent. He had to receive the oath of allegiance, according to a predetermined formula, which the master had to give to the pontiff and to the Roman Church in the presence of the king.

The following passage of the bull is dedicated entirely to the oath and the homage due to the sovereign by the master. It stated that not only should the former pledge allegiance and loyalty to the latter, but also that he should report to the 
king any plots hatched against him or the kingdom, and to prevent any "harm".2 The apostolic letter also emphasized that such an oath was not to be given "by reason of the order's patrimony"; rather, it affected only the Master himself. Immediately afterwards, the pope made it very clear that this did not grant Dinis any rights over the assets of the new order. ${ }^{3}$ Furthermore, he added that the king had ten days to accept the oath, after which the master was authorized to start exercising his magisterium freely.

Pope John XXII also stipulated that the master, grand commander, lieutenant and other commanders of the order were to be admitted to the royal court, and would be able to perform functions similar to those carried out by members of the Order of the Knights of Saint John of Jerusalem; and that in case the mastership fell vacant as a result of withdrawal, death or other reasons, the convent would be tasked with finding a new one, who had to be both a military and a religious man and had to be chosen from among the professed brothers, following the example of the Order of Calatrava.

In conclusion, the ambassadors promised that the king would accept and respect all the papal resolutions as confirmed by the litera procurationis of the monarch given to them and transcribed at the end of the bull. With this letter, dated August I 4, I 3 18, the sovereign sent his agents to Avignon ad tractandum, ordinandum et compositionem faciendum, seu componendum the issue of the administration of the properties of the extinct Order of the Knights Templar in Portugal, as well as that of the assets held in the kingdom by any other military order, demanding the pope confer this task to one or several masters. ${ }^{4}$ In issuing these instructions, the Portuguese ruler - facing matters concerning not only the Templars but all of the military orders of the kingdom (namely the local branch of the Order of Santiago, as will later be seen) - left the decision-making process to his own officials in the Apostolic See and, above all, to the pope himself. It should be noted that in this document King Dinis did not make any concrete reference to the future Order of Christ, including the name by which it was to become known. ${ }^{5}$

2 Behind these words can be felt the echoes of the clashes taking place years before and at that time in the country; see below.

3 Monumenta Henricina (as n. 1) vol. 1, doc. 61, p. 107: Volumus supradicto nullumque ipsi Regi ex juramento vel homagio supradictis in bonis eisdem quomodolibet jus acquiri.

4 Ibidem, vol. 1, doc. 58, pp. 88-89.

5 This circumstance suggests that, perhaps, naming the order was the responsibility of the papal curia. This hypothesis is supported by the words used by the pope in the bull for the election of the first master of the Order of Christ in which John XXII declares: voluimus et in perpetuum volumus ordinem milicie Jhesu Christi vocari; see below, and note 3 . Interestingly, the name of the new order recalls that of the Templars, but differs slightly from it. In fact, in the first case the brethren are called Pauperes commilitones Christi (from the Latin commilito, -onis, translated 
The bull closes with the transcript of the formula of the oath sworn by the master to the abbot of Alcobaça, which does not contain any mention of the monarch or of his prerogatives in the new order. The same circumstance can be observed in the apostolic letter dated March I 5, addressed to Gil Martins, which appointed him officially as the first master of the new militia. ${ }^{6}$ No allusion can be found there to any obligation of entering an oath of allegiance and loyalty with the sovereign.

Some time later, on May 5, King Dinis signed the ratification of the bull, approving all the decisions relating to the establishment of the Order of Christ by John XXII, and accepting without objection the contents of the ordinatio, that is the primitive Statute of the Order. The royal act included as witnesses, among others, Geraldo Domingues, bishop of Évora and chancellor of the king, Afonso Sanches, lord of Albuquerque and keeper of the royal wardrobe, illegitimate son of the monarch, and Juan Alfonso de la Cerda, his son-in-law, but did not include the heir to the throne, Infant Afonso. ${ }^{7}$ Moreover, despite the fact that the king's document approved of and ratified the bull, its text did not make any mention to the Order of the Temple and did not claim a special role for the monarch in the life of the new institution.

At this point, it is interesting to note that the 'official' Portuguese documentation destined for the Apostolic See lacks reference to the Order of the Temple, whereas the Order of Christ is always indicated as a nova militia. The same can be observed in a notarial instrument of November I 8, I 3 I 9 , written at the request of the prior of Alcobaça (the chair of the abbey was vacant) for notifying the pope of the canonical foundation of the order as determined in the bull. ${ }^{8}$ Eight months after the release of the papal letter, the ceremony took place in the king's palace at Santarém. The monarch received homage from the master, with a plethora of witnesses, churchmen and laymen attending, but Infant Afonso was once again absent from the witness list. The act reports the solemn oath of allegiance to the pope and the Roman Church, according to the formula in the bull, sworn by the first master Gil Martins on the Holy Gospel received from the hands of the prior of Alcobaça. ${ }^{9}$ However, only two days later, on November 20, another notarial instrument was drawn up at the request of the master and the convent of the Or-

as "brother-in-arms"); in the latter, Milites Jesu Christi (from the Latin miles, militis, translated as "soldier", but at that time also as "knight"). The Templum Salomonis of the original title was omitted.

6 Monumenta Henricina (as n. 1), vol. 1, doc. 63, pp. 119-120.

Ibidem, doc. 66, pp. 124-126.

Ibidem, doc. 67, pp. 126-128.

9 It is curious to note that the ceremony and the oath-taking nonetheless took place many months after the receipt of the bull, and not after the delay of ten days fixed by the pope. 
der of Christ, giving to Dinis, unconditionally and forever, the incomes (fruitos, rrenouos e rrendas) from all the castles, towns and properties that once belonged to the desfeyto ("undone") Order of the Temple and then passed on to the Order of Christ by disposition of the pope. Behind this decision were the very substantial losses to the Crown in maintaining those properties after the Temple had been dissolved. ${ }^{\circ}$ It is very important to emphasize that in this document the first community of the Order of Christ established a concrete association between the old and the new institution, implicitly recognizing itself as the 'material' inheritor of the Templars, and that only the incomes of the properties of the order, and not the possessions themselves, were given over to the king.

The royal diploma of June $24,1319^{11}$ is even more interesting. In this letter, beginning with an arenga which resembles a spiritual testament, Dinis not only mentioned the old and the new orders explicitly in terms of continuity between one and the other, but he also affirmed that the Order of Christ was the result of the reformação ("reform") of the Order of the Temple. ${ }^{12}$ Furthermore, he renounced the entire Templar patrimony, categorically stating the lack of rights over it, because it had been assigned to the Crown through an unfair sentence. Therefore, he declared his intention to "give back" to the new order all of the land and castles. In addition, the monarch justified his decision by saying he wished to correct and amend for all his mistakes and to 'clean' his conscience, specifying that he did so for himself and for Prince Afonso, who would inherit the kingdom.

This heartfelt admission of responsibility and raising of consciousness by King Dinis put a definite end to the issue of the property assets of the Order of the Temple in Portugal and their transfer to the Order of Christ.

\section{The 'Death' of the Order of the Temple ANd the 'Birth' OF The ORDER OF CHRIST (1307-I319)}

The bull of March I 3 I 9 made official the creation of the Order of Christ and so concluded the longa causa, the "long process", which lasted for years, characterized by intensive diplomatic negotiations, tensions and clashes, in and out of the kingdom of Portugal, since the bull Vox in excelso (issued March 22, I 3 I 2) with which

10 Ibidem, doc. 68, pp. 129-131.

11 ANTT, OCCT, manuscript 234, f. 136r-136v.

12 The word "reform" occurs twice in the text: [...] e que se deve tornar a esta ordem que se agora haa de fazer em reformaçao da outra que sobredicta que foy do tempre; [...] aa ordem de da cavalaria de Jesu Christo que se fez em reformaçao daquela que se desfez que foy do tempre; ANTT, OCCT, manuscript 234, f. 136v. 
Pope Clement V, under pressure from Philip IV of France, had declared the Order of the Temple officially extinct. ${ }^{13}$

In fact, since 1307 King Dinis had put in place a series of initiatives aiming to incorporate in the patrimony of the Crown the Portuguese possessions of the Templars, who, at the same moment, were experiencing difficult times across the European continent. ${ }^{14}$

The Order of the Temple had been present in Portuguese territory since I I 28, even before the official foundation of the kingdom ( I I 44), and over time had become a military and economic power as they were feudal lords of several cities and owners of land, castles and other properties (in Soure, Idanha-a-Velha, Idanha-a-Nova, Pombal, Ega, Redinha, Tomar, Almourol, Salvaterra, Segura and elsewhere), concentrated mainly in the center of the country, north of Lisbon, in the ancient regions of Beira Baixa, Beira Interior, Ribatejo and Alto Alentejo. ${ }^{15}$

Even today, the nature of the relations between the Templars and the Portuguese monarchy remains the subject of historical debate that sees on, one side, those who consider the Portuguese branch of the order an auxiliary arm of the

13 M. Barber, The trial of the Templars, Cambridge 2006; A. Demurger, Jacques de Molay: le crépuscule des Templiers, Paris 2007; J. Théry, Procès des Templiers, in: Prier et combattre. Dictionnaire européen des orders militaires du Moyen Âge, ed. N. Bériou, P. Josserand, Paris 2009, pp. 743-751. See also the well-documented and much studied case of the Templar Trial in Aragon, beginning with A. Forey, The Fall of the Templars in the Crown of Aragon, Aldershot 2001.

14 F. Lopes, Das actividades politicas e religiosas de D. Fr. Estêvão, bispo que foi do Porto e de Lisboa, Lusitania Sacra 6 (1962-1963), pp. 25-90 (reprinted in Colectânea de Estudos de História e Literatura pelo Frei Fernando Félix Lopes, vol. 2, Lisbon 1997, pp. 95-152); R. da Costa, D. Dinis e a supressão da Ordem do Templo (1312): o processo de formação da identidade nacional em Portugal, in: Cultura e Imaginário no Ocidente Medieval. Arrabaldes - Cadernos de História. Série I, Niterói 1996, pp. 90-95; C. Porro, Reassessing in the Dissolution of the Templars: King Dinis and their suppression in Portugal, in: The Debate on the Trial of the Templars, ed. J. Burgtorf, P. Crawford, H. Nicholson, Farnham-Burlington 2010, pp. 171-182; J. Baeta, D. João Lourenço, mestre da Ordem de Cavalaria de Cristo e leal servidor do rei D. Dinis: o seu papel na estruturação da nova ordem militar dionisina, MA dissertation, Universidade de Lisboa, Lisbon 2011; S. A. Gomes, A Extinção da Ordem do Templo em Portugal, Révista de História da Sociedade e da Cultura 11 (2011), pp. 75-116.

15 About the history of the Templars in Portugal and the literature existing on this issue, see L. F. Oliveira, Ordens Militares, in: Ordens Religiosas em Portugal: Das Origens a Trento. Guia Histórico, ed. B. Vasconcelos e Sousa, vol. 5, Lisbon 2005, pp. 453-502; K. Toomaspoeg, L'Ordre du Temple en Occident et au Portugal, in: A Extinção da Ordem do Templo, ed. José Albuquerque Carreiras, Tomar 2012, pp. 17-61; idem, Historiographie de l'Ordre du Temple au Portugal: status quaestionis, in: I Colóquio internacional. Cister, os Templários e a Ordem de Cristo. Actas, ed. J. Albuquerque Carreiras, G. Rossi Vairo, Tomar 2012, pp. 171-191. 
Crown ${ }^{16}$ and, on the other, those who, more recently, have underlined the position of substantial autonomy from central power enjoyed by the order until the ascent of Dinis to the throne, in February I 279. ${ }^{17}$ From that time, the sovereign expressed a continuing interest in the Templars: in August I 279, he granted them protection, ${ }^{18}$ in $\mathrm{I} 285$ he confirmed all their rights and privileges in the kingdom, ${ }^{19}$ for several times he intervened in their favour in local disputes $\left(\mathrm{I} 285,{ }^{20} \mathrm{I}_{2} 86,{ }^{21}\right.$ $1302^{22}$ ), and he made donations to Vasco Fernandes ( $\left.1298,{ }^{23} \mathrm{I}_{30} 4^{24}\right)$, the last master of the order in Portugal, who was already in office in $\mathrm{I} 293 .{ }^{25}$

The situation changed direction at the time of the Trial of the Templars, when the monarch began to act tenaciously on several fronts in an attempt to pursue the goal of taking possession of the very substantial Templar patrimony.

By taking advantage of the difficult situation faced by the order and in wanting to satisfy the dictates of the Apostolic See (favoured by the fact that the local Templars were mostly of Portuguese origin ${ }^{26}$ ), the sovereign systematically tried to establish his control on the activities and properties of the order in the kingdom. He did this by implementing different strategies and by imposing on the Templars the seizure of their patrimony.

To prove that the possessions of the Temple in Portugal actually resulted from royal donations, made not only to serve God, but also the Crown, Dinis set up

16 J. M. Valente, The New Frontier. The Role of the Knights Templar in the Establishment of Portugal as an Independent Kingdom, Mediterranean Studies 7 (1998), pp. 49-65; idem, Soldiers and settlers: the Knights Templar in Portugal, 1128-1319, PhD thesis, University of California, Santa Barbara 2002; M. C. Ribeiro de Sousa Fernandes, A Ordem do Templo em Portugal: algumas consideraçóes em torno das fontes para o seu estudo, Revista da Faculdade de Letras. História (Porto) 8 (2007), pp. 409-420; eadem, A Ordem do Templo em Portugal (das origens à extinção), $\mathrm{PhD}$ thesis, Universidade do Porto, Porto 2009.

17 Oliveira (as n. 15); Toomaspoeg, L'Ordre (as n. 15).

18 1279, August 22, ANTT, Gav. 7, maço 10, doc. 12.

19 1285, May 30, ANTT, Gav. 7, maço 16, doc 2 (transcription from 1318 September 30, 1318) and ANTT, LN-LM, f. 23, col. 2 (fifteenth-century copy).

20 1285, July 13, ANTT, Gav. 7, maço 16, doc. 2 and ANTT, LN-LM, f. 24r, col. 2.

21 1286, July 10, ANTT, Gav. 7, maço 16, doc. 2 and ANTT, LN-LM, f. 25r, col. 1.

22 1302, December 14, ANTT, Gav. 7, maço 9, doc. 16.

23 1298, September 27, ANTT, Gav. 7, maço 16, doc. 2 and ANTT, LN-LM, f. 25r, col. 2.

24 1304, September 14, B. da Costa, Historia da Militar Ordem de Nosso Senhor Jesus Christo, Coimbra 1771 (repr.: Lisbon 1988), doc. 80, p. 298.

25 Vasco Fernandes appears at first already in 1293 as a Templar commander in Santarém: 1293, June 5, ANTT, OCCT, Documentos particulares, maço 1, doc. 29, and ANTT, OCCT, manuscript 234, II, f. 13r-13v.

26 This is the image given by the existing primary sources: for example, in June 1293 (see the previous note), we can find names like Lourenço Martins, Gil Fernandes Barredo, Vasco Fernandes, Rui Gonçalves, Soeiro Anes, Afonso and Martinho. 
a special commission, composed by men loyal to him (Martinho Pires de Oliveira, archbishop of Braga, João Martins de Soalhães, bishop of Lisbon, João das Leis, doctor of Law, Estêvão Miguéis, guardian of the Franciscan province of Lisbon, and a certain Rui Nunes), who had to judge, in the law court, the issue of the ownership of the Templar properties. Between 1307 and the beginning of 1310 , the commission stated that all the land under discussion belonged to the sovereign, ignoring the protests of the Templars who challenged the legitimacy of this sentence as it was considered not to be impartial. ${ }^{27}$

Immediately after this ruling was passed, on January 2 I, I 3 I 0 , Fernando IV of Castile and Dinis signed an agreement in which they promised to protest in the event the papacy decided to allocate the Templar heritage in their respective kingdoms to the Order of Saint John of Jerusalem. They affirmed that in case the Apostolic See made any such claims, they would argue that the properties had been granted to the Templars to serve God but also the monarchy. The pact also stated that Jaime II of Aragon was ready to sign the agreements. ${ }^{28}$

Meanwhile, in 13 ro, provincial councils in Tordesillas (April) and Salamanca (October) were held, during which all the Templars of Hispania were summoned to defend themselves against accusations. The results of investigations carried out on these occasions declared the innocence of the brethren on most grounds, but the inquisitors left the decisions about their fates to the will of the pope. In the Council of Vienne, which began on October I 6, I 3 I I and ended on May 6, I 3 I 2 , after the publication of the bull extinguishing the Temple, the prelates of the kingdoms of Portugal, Castile, Aragon and Majorca managed to obtain a special status for the local Templar patrimony. In fact, in the papal letter of May $2,{ }^{29}$ Pope Clement $\mathrm{V}$ decreed the transfer of the Templar heritage to the Order of Saint John of Jerusalem, with the exception of assets held in Iberia. A few days later, on May 6, the pope also stated that former Templars could be judged locally. ${ }^{30}$ However, on August 23 he wrote to the Iberian sovereigns, returning to the issue and asking for clarification of their intentions about the fate of the Templar properties, giving them a deadline of February I, I 3 I 3 , to respond. ${ }^{3+}$

It can be deduced from this explicit request by the pope that the Templar issue in Portugal was not closed nor resolved at all in favour of the sovereign and that

27 Lopes (as n. 14), pp. 108-109.

28 ANTT, Gav. 7, maço 4, doc. 9, and ANTT, OCCT, manuscript 234, II, f. 10v-11r, ed. Monarquia Lusitana. Sexta Parte, ed. A. da Silva Rego, A. A. Banha de Andrade, A. Dias Farinha, E. dos Santos, Lisbon 1980, pp. 109-110, see also Gomes (as n. 15), pp. 93-94.

29 Regestum Clementis papae $V$, vol. 6, Rome 1887, docs. 7885-7886, pp. 65-71.

30 Ibidem, doc. 8784, pp. 347-349.

31 Lopes (as n. 14), p. 115. 
the conclusions of the committee set up by the king from 1307 to I 3 I O were not actually taken into account by the Apostolic See, but ignored and therefore never approved.

In an attempt to satisfy the demands of the pope, in April I 3 I 4 Dinis carried out an enquiry consisting of 25 questions in Soure, Castelo Branco, Montalvão and Nisa, so as to prove that the Templar properties had their origins in royal donations made during the time of the count Afonso Henriques (later, Afonso I of Portugal). ${ }^{32}$ Among the witnesses interrogated there were former brethren, but also local inhabitants or people related to the Templar commanderies. The statements were based more on vox populi and on oral tradition than on written acts and documents. A few months later, on November i s, the bishop of Lisbon ordered a new enquiry in Tomar ad effectum ut ville, castra et cetera que [Templarii] possidebant ex regia corona ad illam reverterentur. ${ }^{33}$

The results of the two enquiries were most probably never shown to the papal court, as Pope Clement V died on April 20, I 3 I 4, and the Holy See remained vacant until the election of his successor, John XXII, in August 7, I 3 I 6. As a consequence of the situation in Avignon, the issue of the Templar patrimony in Portugal remained pending.

However, it is necessary to clarify that, at the time of the enquiries, Estêvão Miguéis had been recently elected as the head of the diocese of Lisbon. Chaplain, confessor and ambassador of the king, Miguéis was a native of Évora and an educated man of letters. Between I 307 and I 310 , as guardian of the Franciscan province of Lisbon, he had served the commission that assigned the ownership of Templar towns and properties to the Crown. ${ }^{34}$ Subsequently, in 13 I 0 he was chosen as bishop of Porto at the request of the king,, ${ }^{35}$ and in 13 I 3 moved to the head of the Lisbon diocese, at the express wish of the pope. ${ }^{36}$ Even before this, in I 3 I I he was appointed as inquisitor by Clement $\mathrm{V}$ during the Trial of the Templars in Portugal (with permission to use torture during the interrogations). ${ }^{37}$ While in charge of these duties, he had taken part in the councils of Tordesillas, Salamanca

32 Gomes (as n. 15), pp. 100-116.

33 This enquiry is known in a single copy, found in a manuscript of the modern era, conserved in 1800 in the archives of the cathedral of Lisbon: see Lopes (as n. 14), pp. 117-118. Lopes could not consult this document and reports the notice from R. da Cunha, Historia ecclesiastica da Igreja de Lisboa, Lisbon 1642, p. 234; and J. A. de Figueiredo, Nova História da militar ordem de Malta é dos Senhores Grão-priores della em Portugal, vol. 1, Lisbon 1800, pp. 14-15.

34 Lopes (as n. 14), pp. 106-110.

35 Documentos de Clemente V (1305-1314) referentes a España, ed. S. Domínguez Sánchez, León 2014, doc. 618, pp. 625-626.

36 Ibidem, doc. 1336, p. 1271.

37 Ibidem, docs. 795-796, pp. 780-781; and doc. 897, pp. 884-885. 
and Vienne. In addition, he was named by Pope John XXII, or more likely by his predecessor Clement $\mathrm{V}$, as the sole administrator of the patrimony of the extinct Templars in Portugal. On all these occasions and incumbencies, while defending the cause of the sovereign, he had always respected the instructions and indications of the Apostolic See. But it was from I 316 onwards that relations between Estêvão Miguéis and Dinis definitively cracked - an episode that also coincided with some facts that involved members of the bishop's family, as two of his nephews were sentenced to death by the king in Lisbon. ${ }^{38}$

\section{The creation of the Order of Christ in the context of the CIVIL WAR (I3I7-I3I9)}

In reality, at this point in time an atmosphere of great tension was felt in the kingdom of Portugal, with the first concrete signs of the violent clash between King Dinis and the heir to the throne, Infant Afonso, culminating in civil war in I 319.39 The apostolic letters, sent to Portugal in June 1317 by an alarmed John XXII, indicate that a state of war already existed between 1316 and 13 1 7 . The pope had been informed by Dinis's ambassadors about the ongoing conflicts between the sides supporting either the king or the prince. ${ }^{40}$ In this first series of letters, the pontiff (threatening anyone who disturbed the peace of the kingdom with severe penalties, including excommunication) did not mention the people involved; even if, in some cases, it is possible to perceive that they were high-ranking. However, in the second series of letters, of March I 3 I 8 , the pope addressed the protagonists

38 Lopes (as n. 14), p. 122 and following.

39 The Portuguese civil war was studied in F. Lopes, Santa Isabel na contenda entre D. Dinis e o filho 1321-1322, Lusitânia Sacra 8 (1967-1969), pp. 57-80; J. Antunes, A. Resende de Oliveira, J. Gouveia Monteiro, Conflitos politicos no reino de Portugal entre a Reconquista e a Expansão. Estado da questão, Revista da História das Ideias 6 (1984), pp. 25-160, notice p. 112-120; J. Mattoso, A guerra civil de 1319-1324, in: Portugal medieval: novas interpretaçóes, Lisbon 1992, pp. 293-308. It has been revisited in G. Rossi Vairo, Isabelle d'Aragon, reine du Portugal, «constructrice de paix» durant la guerre civile (1317-1322)? Étude critique des sources portugaises et des Regesta Vaticana, in: Médiation, paix et guerre au Moyen Age, ed. M. Sot, Paris 2012, pp. 97-107; eadem, Il protagonismo d'Isabel d'Aragona, regina del Portogallo, nella guerra civile alla luce delle fonti portoghesi, aragonesi e dei Regesta Vaticana (1321-1322), in: Reginae Iberiae. El poder régio feminino en los reinos medievales peninsulares, dir. M. García-Fernández, S. Cernadas Martínez, Santiago de Compostela 2015, pp. 131-150; and more extensively in eadem, D. Dinis del Portogallo e Isabel d'Aragona in vita $e$ in morte: creazione e trasmissione della memoria nel contesto storico e artistico europeo, PhD thesis, Universidade Nova de Lisboa, Lisbon 2014, pp. 107-134, 215-244.

40 Rossi Vairo, D. Dinis del Portogallo e Isabel d'Aragona (as n. 39), docs. XI-XIII, pp. 414-418. 
of the conflict directly, namely the king, the infant, the queen consort (who united with her son in resentment against the monarch), and the bishop of Lisbon. ${ }^{41}$ In this case, the letters singled out Estêvão Miguéis as the one who had created the problems and fuelled the discord within the royal family without giving more details.

If John XXII avoided referring to the assignment taken by the bishop in the administration of the Templar patrimony, it was King Dinis himself who, in the midst of civil war, explicitly recalled all the misdeeds of Miguéis, an affiliate of the prince, and the role he played no feito dos beens do Tenpre ("in the destiny of the Templar properties").42 The monarch referred to this circumstance in a passage of the first of three manifestos published against his rebel son, dated July I, I 320 , having it proclaimed in the squares of the most important towns of Portugal. However, it is interesting to note that the pope, while attributing specific responsibilities to Estêvão Miguéis in the conflict, never took the decision to remove him from the governance of the diocese. Nor did he adopt severe measures against him. So when Dinis wrote to the pontiff, asking him to commit the ungrateful prelate to trial, he responded by saying that he had not collected sufficient evidence against the bishop's actions and therefore could not act against him as the king required. ${ }^{43}$

Therefore, the issue of the fate of the Templar patrimony contributed to the context of strong tension experienced at the time in Portugal. The protest of December 2 I, I 3 1 7, written on behalf of Infant Afonso by his procurator, the lawyer Gomes Lourenço, one of the most vivid supporters of the rebel prince, bears testimony to this. It contested the cession of Tomar, the former headquarters of the Temple in Portugal, to Cardinal Bertrand of Montfavez, title holder of Santa Maria in Aquiro, and formalized by the pope in the same year. ${ }^{44}$ In the midst of the first violent phase of crisis within the kingdom, this extensive document, which was prepared at the request of the prince, and not the king, exposed for the first time the Portuguese thesis of the origins of Templar patrimony. It officially presented to the papal curia the claims and grievances of the Crown on this issue, based essentially on the contents of the I 3 I 4 enquiry - which is but implicitly referred to.

41 Ibidem, docs. XIV-XIX, pp. 418-425; and see also Lopes, Santa Isabel (as n. 39); and Rossi Vairo, Isabelle d'Aragon (as n. 39).

42 F. Lopes, O primeiro manifesto de el-Rei D. Dinis contra o Infante D. Afonso seu filho e herdeiro, Itinerarium-Colectânea de Estudos XII, 55 (1967), pp. 17-45.

43 1318, March 21, Lopes, Santa Isabel (as n. 39), pp. 29-30.

44 1317, December 21, ANTT, Gav. 7, maço 11, doc. 1; and ANTT, OCCT, manuscript 234, II, f. 4r-9r. 
The document lays out a series of dispositions. Firstly, that Tomar and all the other castles, towns and properties were given to the Templars by the first king of Portugal, Afonso Henriques, and his successors, as temporary concessions in exchange for their military service against the "Saracens" or any other enemy, however belonging to the Crown. Secondly, that not only the king but also the members of his family (as the prince or the queen) could use this patrimony and its incomes. Thirdly, that the Templars were subject to royal jurisdiction. The document proceeds by saying that any master, commander or administrator of the order in Portugal could be appointed to office solely with the king's agreement and had to be a native of the kingdom; that a provincial chapter could not be held without royal permission; and that this permission was also necessary for sending monetary resources from Portugal to the master of the order in the Holy Land.45 Moreover, the commanders of the order were required to swear an oath of allegiance to the king and act as simple royal administrators of their patrimony - that this, homage had to be performed not only before every new king, but also to the infant and heir to the throne on his birth (obsculabantur sibi manum et faciebant sibi homagium seu vassallagium), Finally, in the case of war, the brethren and the inhabitants of the towns and villages of the order had to serve the king during military expeditions or else to pay him a monetary contribution.

The precise motivations that drove the infant to behave in this way are not documented by the primary sources, but the issue was likely related to a strong personal interest of Afonso in those territories, which produced huge incomes and were located in a strategic crossroads. A few years later, however, during the civil war, Tomar took the side of the king and the infant unsuccessfully laid siege to the castle. Furthermore, there are several reasons to think that Dinis was not aware of his son's initiative, considering the political context in which the document was written; nor is there comprehensive justification for the belief that this act was ordered by the king, because it could undermine his authority. It is, however, likely that Estêvão Miguéis, bishop of Lisbon, the apostolic administrator of the Templar patrimony in Portugal and a Franciscan like Cardinal Montfavez, had to be informed, or was even one of the promoters of the protest. In fact, at the time he was allied to the rebel prince (and the queen consort), to the point of being referred to in the apostolic letters of March I 3 I 8 because of his behaviour.

45 At this point, there is an interesting difference between the royal enquiry of 1314 and the protest of Afonso: in 1314 it was affirmed that, according to some Templars, the king was considered to be "tight-fisted" and reluctant to let the Templars export their money to Accon, while in 1317 the Templars were said to have considered the Portuguese kings "straightforward" (simplices), as they had let them send the resources to the Holy Land, even if that money belonged to the Crown. 
The initiative of Afonso could not have been viewed favourably by his father, who continued patient diplomatic negotiations through his ambassadors in Avignon. One of them was the Genoese Emanuele Pessagno, appointed grand admiral of the kingdom on February I, I 3 17, during a solemn ceremony at the palace in Santarém, in the presence of the royal family after the former admiral, Nuno Fernandes Cogominho, chancellor of the infant, had voluntarily gone into exile in Castile in $1316 .{ }^{46}$

Emanuele Pessagno, or Manuel Pessanha as he is called in the Portuguese sources, was a figure completely outside the disputes and power games in the realm. It was for this reason that he had been contacted and hired at Avignon by the emissaries of Dinis, the knights Vicente Anes Cesar and João Lourenço, the same who had been there during the discussion about the fate of the Templars' assets, between the end of 1316 and the beginning of $1317 .{ }^{47}$ As ambassador, counselor and confident of the king, Emanuele Pessagno was often sent to Avignon in order to inform the pope of the critical situation in the kingdom ${ }^{48}$ as a result of the conflict within the royal family, but also with regard to the future of the military orders in Portugal.

In fact, Pessagno was commissioned by the king to expose to the papal curia the reasons for the independence of the Portuguese branch of the Order of Santiago, as is stated in a document from I 3 I 8 or I 3 I $9 .{ }^{49}$ Along with this document, the envoy addressed a petition to the pope, pleading for the autonomy of the branch and its separation from the order's centre in Léon and Castile, leaning on a range of very interesting affirmations, which resembled, in some ways, the issue of the foundation of the Order of Christ. According to the admiral, the brethren of Santiago in Portugal had to defend not only Portugal but also its neighbouring countries (like Castile) from the "Saracens" attacking from the south, but the master of the order in Castile had kept to himself the incomes of their possessions, neglecting their necessities and diminishing their military capacities. The brethren had also been forced to participate in the wars between Castile and Portugal. There was obviously an intent to build a military force destined to defend the southern coast of the kingdom, and the same was the case with the Order of Christ, financed by the incomes of the military orders which could no longer be removed from Portugal.

46 About Nuno Fernandes Cogominho, see J. A. Pizarro, Linhagens Medievais Portugueses. Genealogias e Estratégias (1279-1325), vol. 2, Porto 1999, pp. 62-64.

47 G. Rossi Vairo, Ogenovês Micer Manuel Pessanha, Almirante d'El-Rei D. Dinis, Medievalista 13 (2013), on-line edition.

48 Emanuele Pessagno was surely at Avignon in March-April and June-July 1318; see ibidem.

49 Monumenta Henricina (as n. 1), vol. 1, doc. 59, pp. 90-95; As Gavetas da Torre do Tombo, II (Gav. III-XI), Lisbon 1962, pp. 409-413. 
Emanuele Pessagno was well-received in the Apostolic See. He was a member of an ancient family of merchants and navigators, brother of the well-known Antonio, who served the king of England and was implicated in the administration of the former Templar patrimony. ${ }^{50}$ King Dinis entrusted him with the renewal of the Portuguese navy, a programme which would have required people and financial resources, including some of the incomes from the ancient Templar proprieties. Beyond this aim, which was effectively achieved, it is possible that it was the king's will to revive in Portugal the project of the Order of St Mary of Spain, undertaken in his time by Afonso X of Castile. ${ }^{\text {.1 }}$ During its short existence, St Mary of Spain represented an 'abnormal military order', with an eminently maritime and secular vocation, led by an admiral, the Infant Sancho of Castile, but collapsing just ten years after its establishment by the Castilian monarch, having never received the 'papal blessing.'.2

So, it was only in 1319 , after years of negotiation and embassies seeking the most advantageous compromise for the parties involved, that, in fact, the Templar issue had its final breakthrough with the foundation of the Order of Christ on March I 4.

Portuguese historiography has always considered the creation of the Order of Christ as another diplomatic success of King Dinis, a mythical figure in the history of Portugal, who, over the centuries, has been attributed numerous epithets including that of Pater patriae. ${ }^{33}$ A popular motto still affirms that D. Dinis fez tudo quanto quiz: "Dinis was able to do all he wanted". But, as is so often the case, the study of the facts and documents tells a different story. It is true that in the end the Portuguese monarch was capable of laying his hands on the Templar patrimony. But it is equally true that only the incomes of the former Templar lands were taken over by the king, who also requested, in 13 I 8 , the transcription of a series of documents proving the rights and privileges enjoyed by the order (not by himself or the Crown!) since I I $28 .{ }^{54}$ Moreover, this operation was neither easy or obvious. Above all, it was not designed, managed, nor conducted independently by the sov-

50 N. Fryde, Antonio Pessagno of Genoa, King's merchant of Edward II of England, in: Studi in memoria di Federigo Melis, vol. 2, Naples 1978, pp. 159-178; G. Airaldi, Due fratelli genovesi: Manuele e Antonio Pessagno, in: Estudos em homenagem ao Professor Doutor José Marques, vol. 2, Porto 2006, pp. 139-146; J.-M. Roger, Antonio Pessagno, in: Prier et combattre (as n. 13), p. 98.

51 Rossi Vairo, A guerra civil portuguesa, o almirante Manuel Pessanha e a criação da Ordem de Cristo.

52 P. Josserand, Église et pouvoir dans la Péninsule Ibérique. Les ordres militaires dans le royaume de Castille (1252-1369), Madrid 2004, pp. 621-626; J. Torres Fontes, Santa Maria de España, in: Prier et combattre (as n. 13), pp. 845-846; C. de Ayala Martínez, La Orden del Císter y las órdenes militares, in: I Colóquio internacional (as n. 15), pp. 45-85, notice pp. 68-70.

53 J. A. S. M. Pizarro, D. Dinis, Lisbon 2005.

54 1318, September 30, ANTT, Gav. 7, maço 16, doc. 2 ; and ANTT, LN-LM, f. 23r-28v. 
ereign. If, without any doubt, Dinis was one of the protagonists of the long process ending with the institution of the new order, it is also necessary to recognize the contribution made by other personalities from the Portuguese side - the ambassadors, the grand admiral, the infant and, of course, the bishop of Lisbon - who played a decisive role in the gestation and subsequent reaching of the goal, and whose action conditioned, for better or worse, the outcome of the negotiation.

The historical context of Portugal at the beginning of the fourteenth century, especially with reference to the conflict between King Dinis and his heir, Infant Afonso, has also to be taken into consideration while evaluating the shift from the Order of the Temple to the Order of Christ. It is evident that the acquisition of Templar patrimony, as well as the institution of the new order, were decisively dependent on the decisions of the Apostolic See. The fact that in the bull of I 3 I 9 Pope John XXII made reference to the undefined situation existing in the kingdom of Portugal, confirms that until that date nothing had really changed and that none of the initiatives promoted by the king to obtain a solution that was favourable to him never worked. It is possible to conclude that the Order of Christ could only be established as a result of the support and the 'blessing' of the Papacy: a fact still not accepted by every historian.

The creation of the Order of Christ, which at first sight could seem a linear and predetermined historical process, as with the adherence of the order to the Portuguese monarchy, was mainly an unpredictable event, more complex than has previously been described. Within a very short while, the existence of the new militia went through strong reform due to the initiatives put in place by Afonso IV, who was finally able to establish complete control of the order. However, the success of the project permitted the construction of a bridge between two important institutions: the Order of the Temple, a phenomenon very specific to the middle ages, and the Order of Christ, an important reality of the early modern era, in an age when its maritime vocation was predominant. The role it played in the great discoveries of the New World was to become well known.

\section{SOURCES AND LiterATURE}

"As Gavetas da Torre do Tombo, II (Gav. III-XI)." Lisbon: Centro de estudos históricos ultramarinos, 1962 .

“Monumenta Henricina." Vol. ı. Coimbra: UC Biblioteca Geral I, i 960.

"Regestum Clementis papae V." Vol. 6. Rome: Ex Typographia Vaticana, i 887. 
Rego, António de Silva., Andrade, António Banha de., Farinha, António., dos Santos, Eduardo., edit. "Monarquia Lusitana. Sexta Parte." Lisbon: Imprensa Nacional-Casa da Moeda, I 980.

Sánchez, Santiago D. "Documentos de Clemente V (1305-I3 I 4) referentes a España." León: Universidad de León, 2014.

Airaldi, Gabriela. "Due fratelli genovesi: Manuele e Antonio Pessagno." In Estudos em homenagem ao Professor Doutor José Marques. Vol. 2, I 39-1 46. Porto: Faculadade De Letras da Universidade do Porto, 2006.

Antunes, José de., Oliveira, António R. de., Monteiro, João G. "Conflitos políticos no reino de Portugal entre a Reconquista e a Expansão. Estado da questão." Revista da História das Ideias 6 ( 1984 ): 25- 160.

Ayala Martínez, Carlos de. "La Orden del Císter y las órdenes militares." In I Colóquio internacional. Cister, os Templários e a Ordem de Cristo. Actas, edited by José Albuquerque Carreiras and Giulia Rossi Vairo, 45-85. Tomar: Instituto Politécnico de Tomar, 2012.

Baeta, João. D. João Lourenço, mestre da Ordem de Cavalaria de Cristo e leal servidor do rei D. Dinis: o seu papel na estruturação da nova ordem militar dionisina. MA Dissertation. Lisbon: Universidade de Lisboa, 20 I I.

Barber, Malcolm. The trial of the Templars. Cambridge: Cambridge University Press, 2006.

Costa, Ricardo da. "D. Dinis e a supressão da Ordem do Templo ( I 3 I 2): o processo de formação da identidade nacional em Portugal.” In Cultura e Imaginário no Ocidente Medieval. Arrabaldes - Cadernos de História. Vol. I, 90-95. Niterói: UFF, 1996.

Demurger, Alain. Jacques de Molay: le crépuscule des Templiers. Paris: Payot, 2007.

Fernandes, Maria C. Ribeiro de Sousa. "A Ordem do Templo em Portugal: algumas considerações em torno das fontes para o seu estudo." Revista da Faculdade de Letras. História (Porto) 8 (2007): 409-420.

Fernandes, Maria C. Ribeiro de Sousa. A Ordem do Templo em Portugal (das origens à extinção). PhD Thesis. Porto: Universidade do Porto, 2009.

Forey, Allan. The Fall of the Templars in the Crown of Aragon. Aldershot: Ashgate, $200 \mathrm{I}$.

Fryde, Natalie. "Antonio Pessagno of Genoa, King's merchant of Edward II of England." In Studi in memoria di Federigo Melis. Vol. 2, I 59-1 78. Naples: Giannini, 1978.

Gomes, Saúl A. "A Extinção da Ordem do Templo em Portugal." Révista de História da Sociedade e da Cultura I I (20 I I): 75-I I.

Josserand, Philippe. Église et pouvoir dans la Péninsule Ibérique. Les ordres militaires dans le royaume de Castille (I252-I369). Madrid: Casa de Velázquez, 2004.

Lopes, Félix. "Das actividades políticas e religiosas de D. Fr. Estêvão, bispo que foi do Porto e de Lisboa." Lusitania Sacra 6 (1962-1963): 25-90.

Lopes, Félix. "O primeiro manifesto de el-Rei D. Dinis contra o Infante D. Afonso seu filho e herdeiro." Itinerarium-Colectânea de Estudos XII 55 (1967): 17-45. 
Lopes, Félix. "Santa Isabel na contenda entre D. Dinis e o filho I321-1322." Lusitânia Sacra 8 (1967-1969): 57-80.

Mattoso, José. "A guerra civil de 1319-1324." In: Portugal medieval: novas interpretaçôes, edited by José Mattoso, 293-308. Lisbon: Imprensa Nacional Casa da Moeda, 1992.

Oliveira, Luís F. "Ordens Militares." In: Ordens Religiosas em Portugal: Das Origens a Trento. Guia Histórico, edited by Bernardo Vasconcelos e Sousa. Vol. 5, 453-502. Lisbon: Livros Horizonte, 2005.

Pizarro, José A. Linhagens Medievais Portugueses. Genealogias e Estratégias (I279-1325). Vol. 2. Porto: Universidade Moderna, I 999.

Pizarro, José A. D. Dinis, Lisbon: Círculo de Leitores, 2005.

Porro, Clive. "Reassessing in the Dissolution of the Templars: King Dinis and their suppression in Portugal." In The Debate on the Trial of the Templars, edited by Jochen Burgtorf, Paul Crawford and Hellen Nicholson, 171-182. Farnham-Burlington: Routledge, 20 I $\mathrm{O}$.

Roger, Jean-Marc. "Antonio Pessagno." In Prier et combattre. Dictionnaire européen des orders militaires du Moyen Age, edited by Nicole Bériou and Philippe Josserand, 98. Paris: Fayard, 2009.

Rossi Vairo, Giulia. "A guerra civil portuguesa, o almirante Manuel Pessanha e a criação da Ordem de Cristo." In: VII Encontro internacional sobre Ordens Militares. Entre Deus e o Rei. O mundo das Ordens Militares. Atas. Palmela: GeSOS, 2018 (in press).

Rossi Vairo, Giulia. D. Dinis del Portogallo e Isabel d'Aragona in vita $e$ in morte: creazione e trasmissione della memoria nel contesto storico e artistico europeo. $\mathrm{PhD}$ thesis. Lisbon: Universidade Nova de Lisboa, 2014.

Rossi Vairo, Giulia. "O genovês Micer Manuel Pessanha, Almirante d'El-Rei D. Dinis." Medievalista I 3 (2013): I-I 5 .

Rossi Vairo, Giulia. "Isabelle d'Aragon, reine du Portugal, «constructrice de paix» durant la guerre civile (1317-1322)? Étude critique des sources portugaises et des Regesta Vaticana." In Médiation, paix et guerre au Moyen Agge, edited by Michel Sot, 97- 107. Paris: Éd. du Comité des travaux historiques et scientifques, 20 I 2.

Rossi Vairo, Giulia. "Il protagonismo d'Isabel d'Aragona, regina del Portogallo, nella guerra civile alla luce delle fonti portoghesi, aragonesi e dei Regesta Vaticana (I 32 I- I 322 )." In Reginae Iberiae. El poder régio feminino en los reinos medievales peninsulares, edited by Miguel García-Fernández and Silvia Cernadas Martínez, I3 I-150. Santiago de Compostela: Universidade de Santiago de Compostela, 2015.

Théry, Julien. "Procès des Templiers." In Prier et combattre. Dictionnaire européen des orders militaires du Moyen Agge, edited by Nicole Bériou and Philippe Josserand, 743-75 I. Paris: Fayard, 2009.

Toomaspoeg, Kristjan. "Historiographie de l'Ordre du Temple au Portugal: status quaestionis." In I Colóquio internacional. Cister, os Templários e a Ordem de Cristo. Actas, edited by José Albuquerque Carreiras and Giulia Rossi Vairo, 17 I-191. Tomar: Instituto Politécnico de Tomar, 20 I 2. 
Toomaspoeg, Kristjan. “L'Ordre du Temple en Occident et au Portugal.” In A Extinção da Ordem do Templo, edited by José Albuquerque Carreiras, 17-6 I. Tomar: Instituto Politécnico de Tomar, 2012.

Torres Fontes, Juan. “Santa María de España.” In Prier et combattre. Dictionnaire européen des orders militaires du Moyen Age, edited by Nicole Bériou and Philippe Josserand, 845-846. Paris: Fayard, 2009.

Valente, José M. “The New Frontier. The Role of the Knights Templar in the Establishment of Portugal as an Independent Kingdom." Mediterranean Studies 7 ( 1 998): 49-65.

Valente, José M. Soldiers and settlers: the Knights Templar in Portugal, II28-13I9. PhD Thesis. Santa Barbara: University of California, 2002.

\section{ABstract \\ The dissolution of the Order of the Temple and the creation of the Order of Christ in Portugal}

The present research takes as a point of departure the foundation bull of the Order of Christ, given by Pope John XXII in March I 3 19. A study of the Trial of the Templars in Portugal follows. Finally, the article focuses on the circumstances of the creation of the new order, in the light of the relationship between the Portuguese monarchy and the Apostolic See and of the context of civil war between Dinis of Portugal and his son and heir, the Infant Afonso. The institution of the Order of Christ has traditionally been seen by historians as a very linear process, in which the king's will was imposed on the pope and a well-defined and successful project was carried out. In reality, the archival sources suggest otherwise, in the form of a very complex string of actions, which implicated not only the pope and the king but also the infant, the bishop of Lisbon, the former Templars themselves, and many other actors, often in conflict among each other. The strategies employed by the king were much less successful as they might have appeared, as initial attempts to ascribe the Templar patrimony to the Portuguese Crown did not yield results. In fact, after having carried out an inquiry, in I 314 , to prove the supremacy of the Crown over the Templars and their heritage in Portugal, the king finally changed strategy. After long negotiations, an agreement was reached with the pope permitting the creation of a local military order, the Order of Christ, conceived of in Portugal as the result of a "reform" of the Order of the Temple. The former Templar castles, cities and other possessions were passed on to the new order and King Dinis had to content himself with the revenues generated by that patrimony. 